\title{
INFLUENCE OF ENSO ON WET AND DRY SPELL FREQUENCY FOR RAINFED CROPPING PERIOD OVER TAMIL NADU
}

\author{
M. Vengateswari ${ }^{1 *}$, V. Geethalakshmi ${ }^{2}$, K. Bhuvaneswari ${ }^{3}$, S. Panneerselvam ${ }^{4}$ \\ 1,2,4 Tamil Nadu Agricultural University, Coimbatore, Tamil Nadu, India - vengateswariagmet@gmail.com \\ ${ }^{3}$ M S Swaminathan Research Foundation, Chennai, Tamil Nadu, India.
}

\section{Commission III, WG III/10}

KEY WORDS: El Niño, La Niña, Seasonal rainfall, wet spell, dry spell

\begin{abstract}
:
Several factors are responsible for recent climatic anomalies includes seasonal and inter-annual variability of rainfall in the region in which regional and global sea surface temperature (SST) changes is the most significant factor. It is well recognized that El Niño Southern Oscillation (ENSO) is the dominant mode of climate variability on seasonal to inter-annual scales and its impacts are felt worldwide. Seasonal to inter-annual rainfall fluctuations strongly affect the success of agriculture and the abundance of water resources. Daily rainfall data at district scale was obtained from India Meteorological Department (IMD) for a period of 43 years $(1971$ - 2013) was categorized based on the ENSO episodes and the analysis was performed for the rainfed cropping period (RCP, September -December). A week (7 days) with the cumulative rainfall amount of $50 \mathrm{~mm}$ was considered as one wet spell. Non rainy days observed continuously for a decade (10 days) that period was considered to be one dry spell. Results revealed that El Niño conditions positively influenced the rainfall. Compared to neutral years, La Niña years received less rainfall as it showed the negative deviation in most of districts of Tamil Nadu. More wet spell and lesser dry spell weeks was observed under El Niño condition while the lesser wet spell and more dry spell was observed under La Niña conditions. Higher amount of rainfall during El Niño led to more number of wet spells under El Niño event.
\end{abstract}

\section{INTRODUCTION}

Rainfall is one of the major climatic elements that affects farmer's livelihood and plays a major role in the environment and socioeconomic conditions of Tamil Nadu. Rainfall trend studies reveal that there has been much variability in rainfall over different parts of the world. (Jain and Kumar, 2012). Several factors are responsible for recent climatic anomalies includes seasonal and inter-annual variability of rainfall in the region in which regional and global sea surface temperature (SST) changes is the most significant factor. It is well recognized that El Niño Southern Oscillation (ENSO) is the dominant mode of climate variability on seasonal to inter-annual scales and its impacts are felt worldwide. The ENSO phenomenon is often thought as an irregular inter-annual oscillator that swings between warm and cold Sea Surface Temperature (SST) and low and high surface pressure over the central and eastern tropical Pacific (Philander, 1990). The fluctuations in both Sea Surface Temperatures (SSTs) in the eastern equatorial Pacific and in sea level pressures in the southern Pacific at time scales of two to seven years is referred to the El Niño/Southern Oscillation (ENSO).The warm ("El Niño") and the cold ("La Niña") phases, occurs alternatively. These changes include the modification of the Sea Surface Temperature (SST) for large areas of the Pacific Ocean. The changes in SST modify also the climate in a vast area of the planet (Magana, 1999; Sheinbaum, 2003).

The uncertainty of ENSO - Monsoon relationship in the future warming scenarios. This indicates that understanding and modelling the effects of ENSO including changes in rainfall on agricultural productivity are important both in the current and future climate. Krishnamurthy and Goswami et al., 2006 suggest that the decrease in the Indian monsoon rainfall, associated with the warm phases of ENSO, is due to an anomalous regional Hadley circulation. ENSO plays a significant role in the success or failure of Indian monsoon development. ENSO tends to cause year-to-year variability in monsoon rainfall, which would lead to severe droughts and floods. Understanding the relationship between ENSO and Indian monsoon rainfall is imperative to reduce negative impacts or to take advantage of favorable conditions for successful agricultural activities (Selvaraju, 2003). The unpredictability nature of rainfall is also one of the climate indications denoting the trends of changes within the earth's environment that can affect the natural set up. Seasonal to inter-annual rainfall fluctuations strongly affect the success of agriculture and the abundance of water resources (Kokilavani et al., 2015). Geethalakhmi et al. (2005) studied the linkage between ENSO and seasonal rainfall over Tamil Nadu and noted that during summer monsoon (June through September) the relationship is negative, i.e., rainfall is less than normal during El Niño and vice-versa during La Niña years. In contrast, the relationship during northeast monsoon (October through December) is positive, i.e., rainfall is more than normal during El Niño and vice-versa during La Niña years.

\section{MATERIALS AND METHODS}

\subsection{Description of the study area}

Tamil Nadu is located in the Southernmost tip of the Indian Peninsula between $8^{\circ} 5^{\prime}$ and $13^{\circ} 35^{\prime}$ North latitude and $76^{\circ} 15^{\prime}$ and $80^{\circ} 20^{\prime}$ East longitude (Figure 1) with $960 \mathrm{~km}$ coastline that helps in moderating the summer (less hot) and winter (less cold) temperatures, occupying $7 \%$ of the India's population, $4 \%$ of the land area and $3 \%$ of the water resources(CSO,2011).Out of 3.03 million ha of cultivable land, almost $45 \%$ of the total cultivable area in Tamil Nadu is under dry land agriculture and 
dependent largely on seasonal rainfall (Department of Economics and Statistics, Tamil Nadu, 2010).

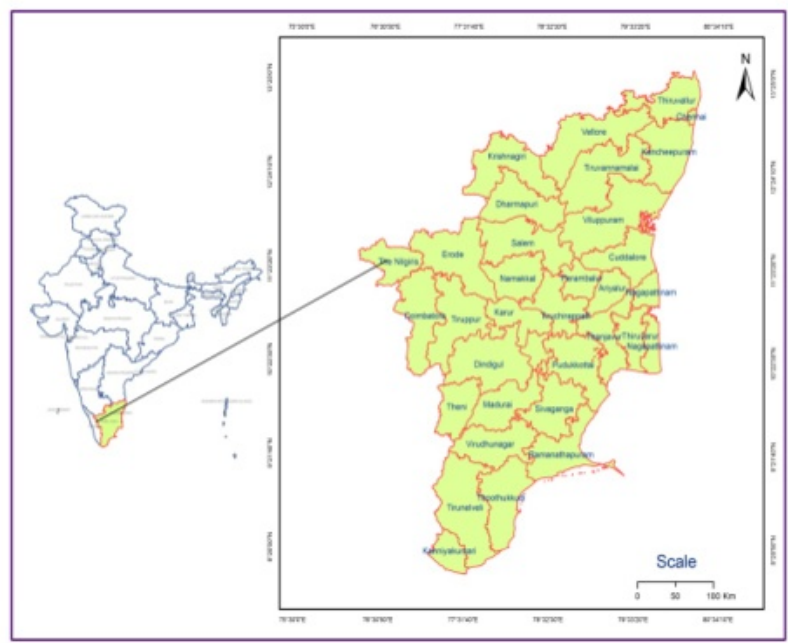

Figure 1. Location of Study area

\section{$2.2 \quad$ ENSO linked climate variability}

Daily rainfall data at district scale was obtained from India Meteorological Department (IMD) for a period of 43 years (1971 - 2013) was categorized based on the ENSO episodes and the wet and dry spell analysis was performed for the rainfed cropping period (RCP, September-December).

El Niño is one of the important factors leading to climate variability. Operationally ENSO conditions are defined based on sea surface temperature variations and their persistence along the equatorial Pacific Ocean. The National Oceanic and Atmospheric Administration (NOAA) define El Niño and $\mathrm{La}$ Niña events based on a threshold of $+/-0.5^{\circ} \mathrm{C}$ for the Oceanic Niño Index (ONI) (3 months running mean of SST anomalies over equatorial eastern Pacific) (http://ggweather.com/enso/oni.htm). ENSO years segregated into two groups as El Niño and La Niña and remaining years were classified under neutral category.'

\begin{tabular}{|c|c|c|}
\hline El Niño & La Niña & Neutral \\
\hline $\begin{array}{l}1972,1976,1977, \\
1979,1982,1986, \\
1987,1991,1994, \\
1997,2002,2004, \\
2006,2009\end{array}$ & $\begin{array}{l}1971,1973,1974, \\
1975,1983,1984, \\
1988,1995,1998, \\
1999,2000,2007, \\
2010,2011\end{array}$ & $\begin{array}{l}1978,1980,1981, \\
1985,1989,1990, \\
1992,1993,1996, \\
2001,2003,2005, \\
2008,2012,2013\end{array}$ \\
\hline
\end{tabular}

Table 1. El Niño, La Niña and neutral years from 1971 to 2013

\subsection{Influence of ENSO on wet and dry spells}

A week (7 days) with the cumulative rainfall amount of $50 \mathrm{~mm}$ was considered as one wet spell. The number of weeks with this condition was counted during entire rainfed cropping period in each year and analyzed based on the categorization of ENSO and neutral years. If non rainy days observed continuously for a decade (10 days) that period was considered to be one dry spell. The number of dry weeks was counted during entire rainfed cropping period in each year and analyzed based on the categorization of ENSO and neutral years.

\section{RESULTS AND DISCUSSION}

3.1

\section{ENSO Effect on wet spell}

El Niño conditions positively influenced the rainfall. Compared to neutral years, La Niña years received less rainfall as it showed the negative deviation in most of districts of Tamil Nadu. The wet spell ranged from 7 to 10 weeks in El Niño years with an average of 9 weeks followed by neutral had 4 to 7 wet spell weeks with an average of 6 wet spell weeks and La Niña had 3 to 6 wet spell weeks with an average of 4 wet spell weeks (Figure 2 and Table 3).

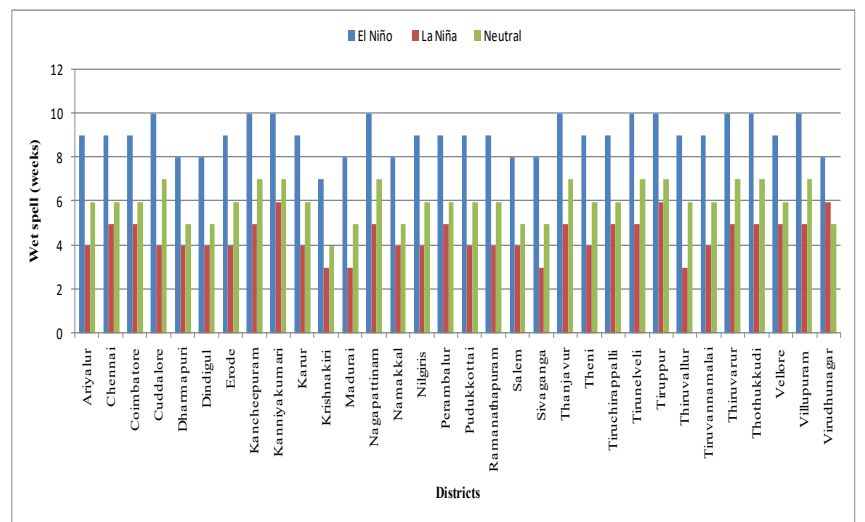

Figure 2. ENSO Effect on wet spell in different districts of Tamil Nadu

\subsection{ENSO Effect on dry spell}

The dry spell ranged from 1 to 5 weeks in El Niño years with an average of 3 weeks. In La Niña phase, the dry spell was from 6 to 8 weeks with an average 10 weeks and neutral had the dry spell from 3 to 6 weeks with an average of 4 weeks (Figure 3 and Table 2).

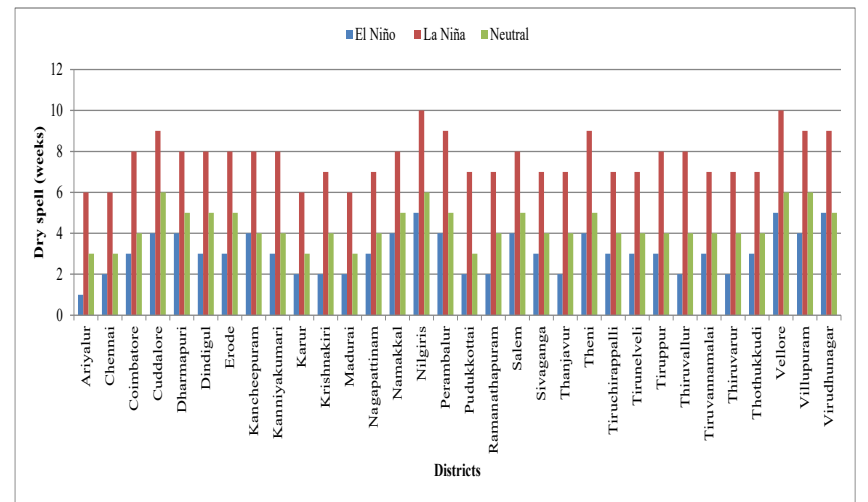

Figure 3. ENSO Effect on dry spell in different districts of Tamil Nadu

More number of wet spells under El Niño conditions might be due to the El Niño induced robust activity of monsoon (North East Monsoon) wind pattern that strongly influence the formation of rain-bearing cloud bands over southern peninsular India (Zubair and Ropelewski, 2006). 


\begin{tabular}{|l|c|c|c|c|c|c|}
\hline \multirow{4}{*}{ District } & \multicolumn{2}{|c|}{ Wet spell (weeks) } & \multicolumn{2}{c|}{ Dry spell (weeks) } \\
\cline { 2 - 7 } & $\begin{array}{c}\text { El } \\
\text { Niñ } \\
\text { o }\end{array}$ & $\begin{array}{c}\text { La } \\
\text { Niñ } \\
\text { a }\end{array}$ & $\begin{array}{c}\text { Neutr } \\
\text { al }\end{array}$ & $\begin{array}{c}\text { El } \\
\text { Niño }\end{array}$ & $\begin{array}{c}\text { La } \\
\text { Niña }\end{array}$ & $\begin{array}{c}\text { Neut } \\
\text { ral }\end{array}$ \\
\hline Ariyalur & 9 & 4 & 6 & 1 & 6 & 3 \\
\hline Chennai & 9 & 5 & 6 & 2 & 6 & 3 \\
\hline Coimbatore & 9 & 5 & 6 & 3 & 8 & 4 \\
\hline Cuddalore & 10 & 4 & 7 & 4 & 9 & 6 \\
\hline Dharmapuri & 8 & 4 & 5 & 4 & 8 & 5 \\
\hline Dindigul & 8 & 4 & 5 & 3 & 8 & 5 \\
\hline Erode & 9 & 4 & 6 & 3 & 8 & 5 \\
\hline Kancheepuram & 10 & 5 & 7 & 4 & 8 & 4 \\
\hline Kanniyakumari & 10 & 6 & 7 & 3 & 8 & 4 \\
\hline Karur & 9 & 4 & 6 & 2 & 6 & 3 \\
\hline Krishnakiri & 7 & 3 & 4 & 2 & 7 & 4 \\
\hline Madurai & 8 & 3 & 5 & 2 & 6 & 3 \\
\hline Nagapattinam & 10 & 5 & 7 & 3 & 7 & 4 \\
\hline Namakkal & 8 & 4 & 5 & 4 & 8 & 5 \\
\hline Nilgiris & 9 & 4 & 6 & 5 & 10 & 6 \\
\hline Perambalur & 9 & 5 & 6 & 4 & 9 & 5 \\
\hline Pudukkottai & 9 & 4 & 6 & 2 & 7 & 3 \\
\hline $\begin{array}{l}\text { Ramanathapura } \\
\text { m }\end{array}$ & 9 & 4 & 6 & 2 & 7 & 4 \\
\hline Salem & 8 & 4 & 5 & 4 & 8 & 5 \\
\hline Sivaganga & 8 & 3 & 5 & 3 & 7 & 4 \\
\hline Thanjavur & 10 & 5 & 7 & 2 & 7 & 4 \\
\hline Theni & 9 & 4 & 6 & 4 & 9 & 5 \\
\hline Tiruchirappalli & 9 & 5 & 6 & 3 & 7 & 4 \\
\hline Tirunelveli & 10 & 5 & 7 & 3 & 7 & 4 \\
\hline Tiruppur & 10 & 6 & 7 & 3 & 8 & 4 \\
\hline Thiruvallur & 9 & 3 & 6 & 2 & 8 & 4 \\
\hline $\begin{array}{l}\text { Tiruvannamala } \\
\text { i }\end{array}$ & 9 & 4 & 6 & 3 & 7 & 4 \\
\hline Thiruvarur & 10 & 5 & 7 & 2 & 7 & 4 \\
\hline Thothukkudi & 10 & 5 & 7 & 3 & 7 & 4 \\
\hline Vellore & 9 & 5 & 6 & 5 & 10 & 6 \\
\hline Villupuram & 10 & 5 & 7 & 4 & 9 & 6 \\
\hline Virudhunagar & 8 & 6 & 5 & 5 & 9 & 5 \\
\hline Maximum & 10 & 6 & 7 & 5 & 10 & 6 \\
\hline Minimum & 7 & 3 & 4 & 1 & 6 & 3 \\
\hline Average & 9 & 4 & 6 & 3 & 8 & 4 \\
\hline
\end{tabular}

Geethalakshmi, V., J. M. Bride and A. K. S. Huda. 2005. Impact of ENSO on Tamil Nadu Rainfall. Vatavaran, 29 (2), pp. 9-16.

Goswami, B. N., Madhusoodanan, M. S., Neema, C. P., \& Sengupta, D. (2006). A physical mechanism for North Atlantic SST influence on the Indian summer monsoon. Geophysical Research Letters, 33(2)

Jain, S. K. and V. Kumar. 2012. Trend analysis of rainfall and temperature data for India. Current Science. 102 (1).

Kokilavani, S., A. P. Ramaraj and S. Panneerselvam.2015. Exploring the relationship of Enso and rainfall variability over southern zone of Tamil Nadu. International Journal of Environmental Science and Technology. 4(4), pp. 955 - 965.

Magana, V. 1999.Los impactos de El Niño en México.Dirección General de Protección Civil, Secretaría de Gobernación, México, pp. 229.

Philander, S. G. 1990. El Niño, La Niña and the Southern Oscillation, Academic Press, Sa Diego, CA., pp.293.

Selvaraju, R. 2003. Impact of El niño-Southern oscillation on Indian food grain production. International Journal of Climatology. 23, pp. 187-206.

Sheinbaum, J. 2003. Current theories on El Niño southern oscillation: A review. Geofisica International., 42, pp. 297 305 .

Zubair, L. and C. F. Ropelewski. 2006. The Strengthening relationship between ENSO and Northeast monsoon rainfall over Sri Lanka and Southern India. American Meteorological Society. 19, pp. 1567-175.

Table 2. Effect of ENSO on wet and dry spells during Rainfed Cropping Period

*- Significant differences considered when $\mathrm{p} \leq 0.05$

(Student's t -test)

More wet spell and lesser dry spell weeks was observed under El Niño condition while the lesser wet spell and more dry spell was observed under La Niña conditions. Higher amount of rainfall during El Niño led to more number of wet spells under El Niño event.

\section{REFERENCES}

CSO, 2011. National Accounts Statistics 2011 and Earlier Issues, Central Statistics Office (CSO), Ministry of Statistics and Programme Implementation, Govt. of India, New Delhi.

Department of Economics and Statistics. 2010. Annual report, Department of Economics and Statistics, Tamil Nadu State, Chennai. http://www.tnstat.gov.in/ annualeport2010.pdf 